\title{
Spectrophotometric Determination of Lamivudine in Pure and Tablet Forms
}

\author{
A. BIKSHAM BABU ${ }^{1}$, G. RAMU ${ }^{1}$, CH. MURALI KRISHNA ${ }^{1}$, \\ S. BRAHMA REDDY ${ }^{2}$, and C. RAMBABU ${ }^{* 1}$ \\ ${ }^{1}$ Department of Chemistry, Acharya Nagarjuna University, \\ Dr.M.R.Appa Row Campus, Nuzvid-521 201, India \\ ${ }^{2}$ Department of Chemistry, \\ BAKR PG College, Ongole, A.P, India \\ rbchintala@gmail.com
}

Received 11 July 2011; Accepted 20 September 2011

\begin{abstract}
Two visible spectrophotometric methods have been developed for the determination of Lamivudine(LMV) in pure and tablet forms. Method-A is based on oxidation of 3-methyl-2-benzathiazolinone hydrazone (MBTH) in the presence of iodoso benzene diacetate (IBDA) to form electrophilic intermediate which is an active coupling species that reacts with the coupler (LMV) by electrophillic attack on the most nucleophilic site on cyclic ring of the coupler. Method-B depends on diazonium salt formation and consequent reaction with resorcinol producing colored product. The absorbances are measured at 590nm and $540 \mathrm{~nm}$ for Method-A and Method-B respectively. Beer's law is obeyed in the concentration range of $10.0-60.0 \mu \mathrm{g} / \mathrm{mL}$ for both the methods. The correlation coefficient which is very close to unity indicates that there is good correlation between concentration and absorbance. LOD, LOQ, confidence levels and relative standard deviation are calculated for the developed methods. The developed methods were successfully applied to tablet forms.
\end{abstract}

Keywords: Lamivudine, Tablets, MBTH, IBDA, Resorcinol, Spectrophotometry.

\section{Introduction}

Lamivudine is chemically known as 2',3'-dideoxy-3'-thiacytidine, commonly called 3TC which is a potent nucleoside analog reverse transcriptase inhibitor. Lamivudine has been used for treatment of chronic hepatitis B at a lower dose than for treatment of $\mathrm{HIV}^{1}$. It is available as formulations in the market such as Epivir $150 \mathrm{mg}$ or $300 \mathrm{mg}$ tablets, EpivirHBV $100 \mathrm{mg}$ tablets Zeffix $100 \mathrm{mg}$ tablets, lamivir HBV as lamivudine $100 \mathrm{mg}$, Lamivir $150 \mathrm{mg}$ Duovir (combination of Lamivudine 150 and Zidovudine 300) and Trioday (Combination of Lamivudine 300, tenofovir 300 and efavirenz 600). Some UV-Visible, HPLC, HPTLC capillary electrophoresis methods are reported for the determination of LMV in formulations, human plasma, plasma, saliva and cerebrospinal fluid, human serum, 
blood cells, urine and blood plasma. UV-spectrophotometric methods are based on the measuring the absorbance of the aqueous solution at $295 \mathrm{~nm}$ and $270 \mathrm{~nm}$ respectively ${ }^{2-3}$. A visible spectrophotometric method is reported which is based on the formation of colored product by condensation of the drug with three aromatic aldehydes such as DMAB, DMAC and Vanillin ${ }^{4}$. Three procedures based on redox and complexation reactions $\left(\mathrm{KMnO}_{4}\right.$-Fast Green $\mathrm{FCF}, \mathrm{NaIO}_{4}-\mathrm{MBTH}$, and $\mathrm{Fe}$ (III)-Ferricynide) ${ }^{5}$ are reported. LMV is also determined by using N-bromosuccinimide-Celestine blue, cobalt thiocyanate and ammonium molybdate as reagents ${ }^{6}$. The drug is also estimated by using $\mathrm{NaNO}_{2}$-phloroglucinol, Folin -cioalteu reagent, $\mathrm{Fe}$ (III)-phenanthroline, $\mathrm{KBrO}_{3}-\mathrm{KBr}$ methyl orange and $\mathrm{KBrO}_{3}-\mathrm{KBr}$ indigocaramine ${ }^{7}$. Reverse Phase HPLC method ${ }^{8}$ has been reported to determine LMV in tablet dosage forms in combination with zidovudine. HPTLC method $^{9}$ is reported for the determination of LMV and stavudine in tablet dosage forms. HPLC technique is applied for the determination of LMV in human plasma $^{10-12}$, cerebrospinal fluid ${ }^{13}$, human serum ${ }^{14}$, blood cells ${ }^{15}$, urine ${ }^{16}$ and blood plasma ${ }^{17}$. Capillary Zone Electrophoresis ${ }^{18}$ is also used in the determination of the drug. Titrimetric and spectrophotometric methods ${ }^{19}$ are also reported for the assay of lamivudine in pharmaceuticals. Recently three HPLC methods ${ }^{20-22}$ and one UV-spectrophotometric method ${ }^{23}$ have been reported for the determination of LMV in combination with other drugs. We now report two visible spectrophotometric methods which are based on oxidative coupling reaction with MBTH and IDBA(Method-A) and diazonium salt formation followed by reaction with resorcinol (Method- B).

\section{Experimental}

An Elico SL159 model, $2 \mathrm{~nm}$ high resolution, double beam, $1 \mathrm{~cm}$ length quartz coated optics with wavelength range $190-1100 \mathrm{~nm}$ is used.

\section{Preparation of solutions}

\section{Standard solution of lamivudine}

Stock solution of Lamivudine $(0.1 \%)$ is freshly prepared by transferring accurately weighed $100 \mathrm{mg}$ of Lamivudine into $100 \mathrm{ml}$ volumetric flask and dissolved in double distilled water, and then made up to the mark. The working standard solution $(200 \mu \mathrm{g} / \mathrm{mL})$ is prepared by transferring $20.0 \mathrm{ml}$ of the stock solution into a $100 \mathrm{~mL}$ standard flask and made up to the mark.

MBTH Solution (Fluka; $8.56 \times 10^{-3} \mathrm{M}$ )

$200 \mathrm{mg}$ of 3-Methyl-2-Benza thiazolinone Hydrazone (MBTH) is accurately weighed, transferred into $100 \mathrm{ml}$ volumetric flask, made up to the mark with distilled water.

IBDA solution (Qualigens; $6.21 \times 10^{-3} \mathrm{M}$ )

$200 \mathrm{mg}$ of Iodoso benzene diacetate (IBDA) is accurately weighed, and dissolved in distilled water.

Resorcinol solution (Fluka; $9.081 \times 10^{-3} \mathrm{M}$ )

$100 \mathrm{mg}$ of Resorcinol is accurately weighed, transferred into $100 \mathrm{ml}$ volumetric flask, made up to the mark with distilled water.

$\mathrm{HCl}$ solution (Qualigens, 0.1M)

$8.6 \mathrm{~mL}$ of Conc. $\mathrm{HCl}$ is diluted to $100 \mathrm{ml}$ with distilled water.

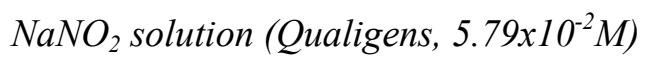


$200 \mathrm{mg}$ of $\mathrm{NaNO}_{2}$ is dissolved in $100 \mathrm{ml}$ volumetric flask with distilled water.

$\mathrm{NaOH}$ solution(E-Merk,20\%,5.0M)

$20 \mathrm{~g}$ of Sodium hydroxide is accurately weighed and dissolved in triple distilled water in $100 \mathrm{~mL}$ volumetric flask.

\section{Procedure}

Method-A

Different aliquots of working standard solution of LMV $(0.5-3.0 \mathrm{~mL})$ are transferred into a series of $10.0 \mathrm{~mL}$ calibrated tubes. Then $1.0 \mathrm{~mL}\left(8.56 \times 10^{-3} \mathrm{M}\right)$ of MBTH solution and $2.0 \mathrm{~mL}$ of IBDA solution are added and kept aside for $5 \mathrm{~min}$. Then the total volume is made up to the mark with distilled water. The absorbance is measured at $590 \mathrm{~nm}$ against a similar reagent blank.

\section{Method-B}

Aliquots of standard LMV solution $(0.5-3.0 \mathrm{~mL})$ are transferred into a series of $10 \mathrm{~mL}$ calibrated tubes, then $1.0 \mathrm{~mL}$ of $0.25 \mathrm{M} \mathrm{HCl}$ solution and $1.0 \mathrm{~mL}$ of cold $\mathrm{NaNO}_{2}$ solution are added and set aside for $10 \mathrm{~min}$ at $0-5{ }^{\circ} \mathrm{C}$ temperature. Finally $2.0 \mathrm{~mL}$ of resorcinol and $1.5 \mathrm{~mL}$ of $\mathrm{NaOH}$ solutions are added and the volume is made up to the mark with distilled water. The absorbance is measured at $540 \mathrm{~nm}$ against a similar reagent blank.

\section{Results and Discussion}

\section{Spectral characteristics}

In order to ascertain the optimum wavelength of maximum absorption $\left(\lambda_{\max }\right)$ of the colored species formed in the each method, specified amount of LMV is taken and color has been developed by following the prescribed procedure. The absorption spectrum is scanned on a spectrophotometer in the region of 380 to $900 \mathrm{~nm}$ against similar reagent blank. The absorption curves are drawn by plotting wavelength against absorbance. The absorption curves of the colored species in each method show characteristics absorption maxima, where as the blank in each method has low or no absorption in this region.

\section{Optical Characteristics}

In order to test whether the colored species formed adhere to Beer's law or not, a series of working standard solutions containing varying amounts of LMV are taken, specified amount of reagents are added, made up to the mark, shaken well and measured the absorbance against the corresponding reagent blank at maximum wavelength. Plots are drawn by taking weight of the drug $(\mu \mathrm{g} / \mathrm{ml})$ on $\mathrm{x}$-axis versus absorbance on y axis and are found to be linear. Beer's law limits, Molar absorptivity, Sandell's sensitivity and Optimum photometric range are calculated and are presented in Table 1. Linear least square regression analysis is carried out for getting the slope, intercept and correlation coefficient values.

\section{Precision and accuracy}

The precision of each proposed method is ascertained from the absorbance values obtained by actual determination of six replicates of a fixed amount of LMV in total solution. The percent relative standard deviation and percent range of error are calculated for the proposed methods. To determine the accuracy of each proposed method, different amounts of bulk 
samples of LMV within the Beer's law limits are taken and analyzed by the proposed method. The results are given in Table 1.

Table 1. Spectral, Optical characteristics, Regression parameters, Precision, and Accuracy of the proposed methods.

\begin{tabular}{clcc}
\hline S.No & \multicolumn{1}{c}{ Name of the Parameter } & Method-A & Method-B \\
\hline 1 & Maximum Wavelength $\lambda_{\max }$ & $590 \mathrm{~nm}$ & $540 \mathrm{~nm}$ \\
2 & Beer's Law Limits $\mu \mathrm{g} / \mathrm{ml}$ & $10.0-60.0$ & $10.0-60.0$ \\
3 & Optimum Photometric Range $\mu \mathrm{g} / \mathrm{ml}$ & $30.0-50.0$ & $30.0-60.0$ \\
4 & Sandell's Sensitivity $\left(\mu \mathrm{g} / \mathrm{cm}^{2} / 0.001 \mathrm{Abs}\right)$ & $1.00 \mathrm{E}-01$ & $1.30 \mathrm{E}-01$ \\
5 & Molar Absorptivity $\mathrm{lt} / \mathrm{mole} / \mathrm{cm}$ & $2.37 \mathrm{E}+03$ & $1.45 \mathrm{E}+03$ \\
6 & Slope $(\mathrm{b})^{\mathrm{a}}$ & $1.03 \mathrm{E}-02$ & $6.34 \mathrm{E}-03$ \\
7 & Intercept $(a)$ & $2.27 \mathrm{E}-03$ & $1.20 \mathrm{E}-03$ \\
8 & Standard Deviation on Slope $\left(\mathrm{S}_{\mathrm{b}}\right)$ & $1.37 \mathrm{E}-04$ & $1.86 \mathrm{E}-04$ \\
9 & Standard Deviation on Intercept $\left(\mathrm{S}_{\mathrm{a}}\right)$ & $5.35 \mathrm{E}-03$ & $7.25 \mathrm{E}-03$ \\
10 & Standard Error on Estimation $\left(\mathrm{S}_{\mathrm{e}}\right)$ & $7.50 \mathrm{E}-03$ & $1.02 \mathrm{E}-02$ \\
11 & Correlation Coefficient $(\mathrm{r})$ & 0.9994 & 0.9971 \\
12 & Standard Deviation $(\mathrm{S})$ & 0.1686 & 0.6757 \\
13 & \%Relative Standard Deviation ${ }^{\mathrm{b}}$ & 0.4221 & 1.6983 \\
14 & 0.05 level confidence limit $\mu \mathrm{g} / \mathrm{ml}$ & 0.2774 & 1.1117 \\
15 & 0.01 level confidence limit $\mu \mathrm{g} / \mathrm{ml}$ & 0.4633 & 1.8566 \\
16 & Limit of Detection $(\mathrm{LOD}) \mu \mathrm{g} / \mathrm{ml}$ & 1.5552 & 3.4326 \\
17 & Limit of Quantification $(\mathrm{LOQ}) \mu \mathrm{g} / \mathrm{ml}$ & 5.1840 & 11.4420 \\
\hline
\end{tabular}

${ }^{a}$ Regression equation $Y=a+b C$, Where $Y$ stands for absorbance and $C$ is concentration in $\mu \mathrm{g} / \mathrm{mL}$,

bo Relative standard deviation is calculated for six determination.

\section{Limit of detection \& limit of quantification}

The limit of detection (LOD) and limit of quantification (LOQ) of the developed methods are evaluated based on the standard deviation of the intercept $\left(S_{a}\right)$, and slope of calibration curve (b).

\section{Analysis of formulations}

Commercial formulations containing Lamivudine are successfully analyzed by the proposed methods. The values obtained by the proposed and reference methods for the formulations are compared statistically (reference method ${ }^{19}$ ) with F-test and t-test and found to be not different significantly. Percent recoveries are determined by adding standard drug to preanalysed formulations. The results of the recovery experiments by the proposed methods are listed in Table 2.

\section{Chemistry of colored products}

\section{Method-A}

MBTH when treated with an oxidizing agent such as IBDA it undergoes oxidation with loss of two electrons and one proton forming an electrophilic intermediate, which is an active 
coupling species that reacts with the coupler (LMV) by electrophillic attack on the most nucleophilic site on cyclic ring of the coupler ortho/para to tertiary nitrogen atom of the drug. The probable sequence of reactions is presented in scheme.

Table 2. Determination of Lamivudine in pharmaceutical formulations.

\begin{tabular}{|c|c|c|c|c|c|c|c|}
\hline \multirow[t]{2}{*}{ Sample } & \multirow{2}{*}{$\begin{array}{c}\text { Amount } \\
\text { Taken }\end{array}$} & & \multicolumn{3}{|c|}{ Amount Found } & \multicolumn{2}{|c|}{$\%$ Recovery } \\
\hline & & & Method-A & Method-B & & Method-A & Method-B \\
\hline \multirow[t]{4}{*}{$\begin{array}{c}\text { Lamivir } \\
\text { (tablet) }\end{array}$} & $100 \mathrm{mg}$ & $\mathrm{AVG}^{\mathrm{a}}$ & 99.99 & 100.20 & $\% \mathrm{REC}^{\mathrm{b}}$ & 99.99 & 100.20 \\
\hline & & SD & \pm 1.90 & \pm 1.86 & $\%$ RSD & \pm 1.900 & \pm 1.856 \\
\hline & & $\mathrm{F}$ & 1.192 & 1.142 & & & \\
\hline & & $\mathrm{t}$ & 1.304 & 1.090 & & & \\
\hline \multirow{4}{*}{$\begin{array}{c}\text { Lamivir } \\
\text { (tablet) }\end{array}$} & $150 \mathrm{mg}$ & AVG & 151.98 & 150.38 & $\%$ REC & 101.32 & 100.25 \\
\hline & & SD & \pm 1.88 & \pm 1.86 & $\%$ RSD & \pm 1.237 & \pm 1.236 \\
\hline & & $\mathrm{F}$ & 1.053 & 1.076 & & & \\
\hline & & $\mathrm{t}$ & 0.538 & 0.833 & & & \\
\hline
\end{tabular}

${ }^{a}$ Average of six determinations are considered, $A V G=$ Average, $S D=$ Standard deviation, $F=F$-test value, $t=t$-test value; Theoretical values at 0.05 level of confidence limit $F=5.05, t=1.812$. ${ }^{b_{0}} \% R E C=\%$ of Recovery, \%RSD $=\%$ of Relative standard deviation; Recovery of $10.0 \mathrm{mg}$ added to the preanalyzed formulations (Average of six determinations).<smiles>Cn1c(=NN)sc2ccccc21</smiles>

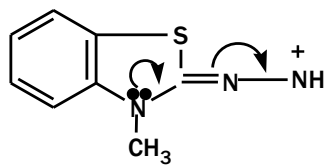

Electrophilic intermediate

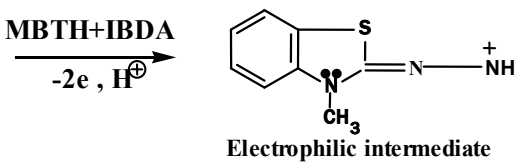<smiles>C[n+]1c(N=N)sc2ccccc21</smiles>

Electrophilic intermediate

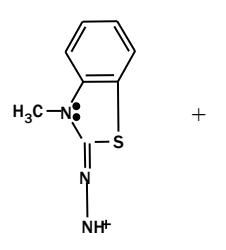

Electrophilic intermediate

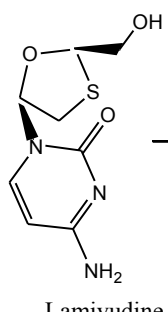

Lamivudine<smiles></smiles><smiles></smiles>

Colour Product 


\section{Method-B}

Lamivudine forms diazonium salt by reacting with sodium nitrite in the presence of hydrochloric acid. The diazonium salt reacted with resorcinol to form a colored complex. The scheme of the reaction is given below.

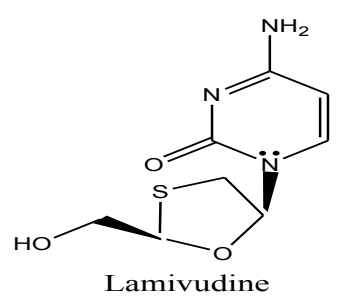

Lamivudine

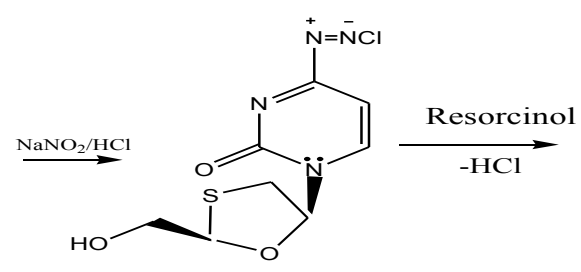

Diazonium Compound

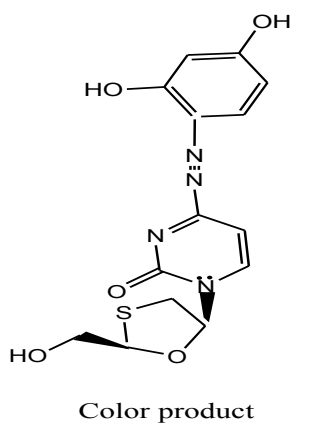

\section{Conclusion}

The developed visible spectrophotometric methods are based on oxidative coupling reaction with MBTH in presence of IDBA(Method-A) and diazonium salt formation followed by reaction with resorcinol (Method- B). The absorbances are measured at $590 \mathrm{~nm}$ and $540 \mathrm{~nm}$ for Method-A and Method-B respectively. Beer's law is obeyed in the concentration range of $10.0-60.0 \mu \mathrm{g} / \mathrm{mL}$ for both the methods. The methods are found to be simple, precise and accurate. These methods can be successfully applied for the analysis of pharmaceutical formulations in any laboratory.

\section{Acknowledgment}

The authors are thankful to Hetero Drugs, Hyderabad for providing gift sample and to the university authorities for providing laboratory facilities

\section{References}

1. Parfitt K, The Complete Drug Reference, The Pharmacopoecial Press London, 1999, 32, 622 .

2. Rajasekara A, Murugesan S, Rajagopal K A, Blessing A G I, Chakravarthy T N and Pusparaj D S I, Oriental J Chem., 2000, 16, 563-564.

3. Sanker D G, Reddy M V V N, Kumar J M R and Murthy T K, Asian J Chem., 2002 14, 433-436.

4. $\quad$ Baig M V, Kapse G S and Raju S A, Asian J Chem., 2001, 13,185-189.

5. Sarma G N, Sastry C K and Sastry C S P, Asian J Chem., 2002,14,683-690.

6. Sharma C S N, Kamala Sastry C and Sastry C S P, Acta Ciencia Indiaca Chem., 2002, 28, 221-225.

7. Appalaraju S, Karadi A B,.Kamalapurkar G S and Sarasambia P S, Asian J Chem 2002,14,475-478.

8. Pallad M S, Rajesh P M N, Chatter M and .Bhat A R, Indian J Pharm Sci., 2005, 67, 110-112.

9. Wankede S B, Gupta K R and Wadodkar S G, Indian J Pharm Sci., 2005,67,96-97.

10. Aymard G,.Legrand M, Trichereau N and Diquet B J, Chromatogr B: Biomed Sci Appl., 2000,744, 227-240.

11. Pereira A S, Kenney K B, Cohen M S, Hall J E, Eron J J, Tidwell R R and Dunn J A, J Chromatogr B: Biomed Sci Appl., 2000,742, 173-183.

12. Fan B and Stewart, J Pharm Biomed Annal., 2002, 28, 903-908. 
13. Hoetelmanur R M W, Profit M, Mecnhorst P I, Mulder J W and Beijnen J H J, Chromatogr B: Biomed Sci Appl., 1998,713,387-394.

14. Ozkan S A and Uslu B, J Liq Chromatogr Rel Technol., 2002, 25, 1447-1456.

15. Moore J D, Valette G, Dorque A and.Zhon J J, Am Soc Mass Spectrum., 2000, 11, 1134-1143.

16. Plumb R S, M.Gray R D, Hasker A J and Taylor S J, Chromatogr B: Biomed Appl., 1996, 687, 457-461.

17. Zhen J J, Wu S T and Emm TA, J Chromatogr B: Biomed Appl., 2001, 761, 195-201.

18. Fan B and Stewar J T, J Liq Chromator Rel Technol., 2002,25, 241-249.

19. Basavaiah K and Somashekar B C, J Sci Indust Res., 2006, 65, 349-354.

20. Nagulwar V P and Bhusari K P, J Pharm Res., 2009,2(4), 666-669.

21. Mainardes R M and Maria P D, Biological Research, Biol Res., 2009, 42, 357-364.

22. Notari S, Mancone C, Alonzi T, Tripodi M, Narciso P and Ascenzi P, J Chromatogr $B, 2008,2(1), 249-257$.

23. Devmurari V P, Int J Pharm Sci Res., 2010, 1(7), 82-86. 


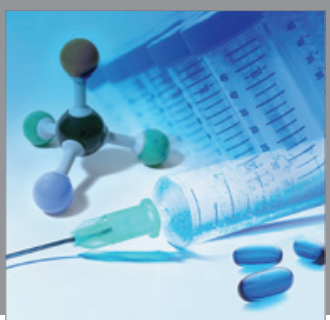

International Journal of

Medicinal Chemistry

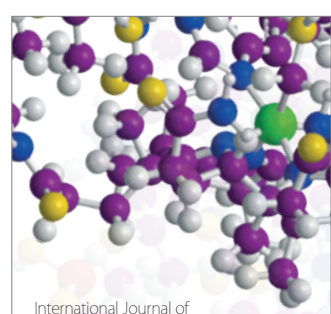

Carbohydrate Chemistry

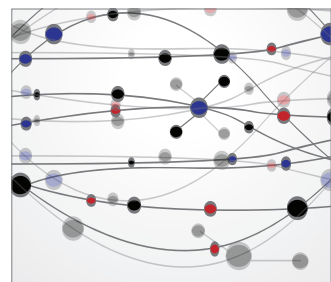

The Scientific World Journal
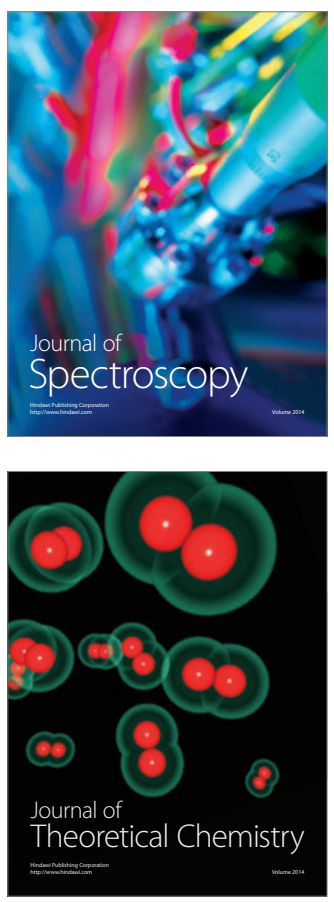
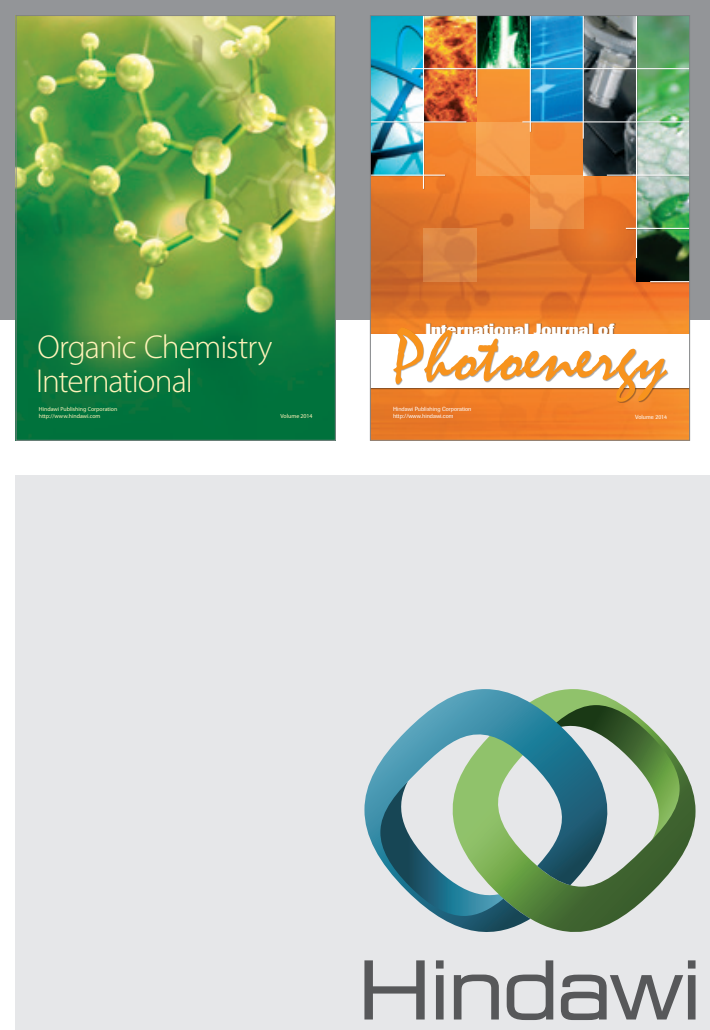

Submit your manuscripts at

http://www.hindawi.com
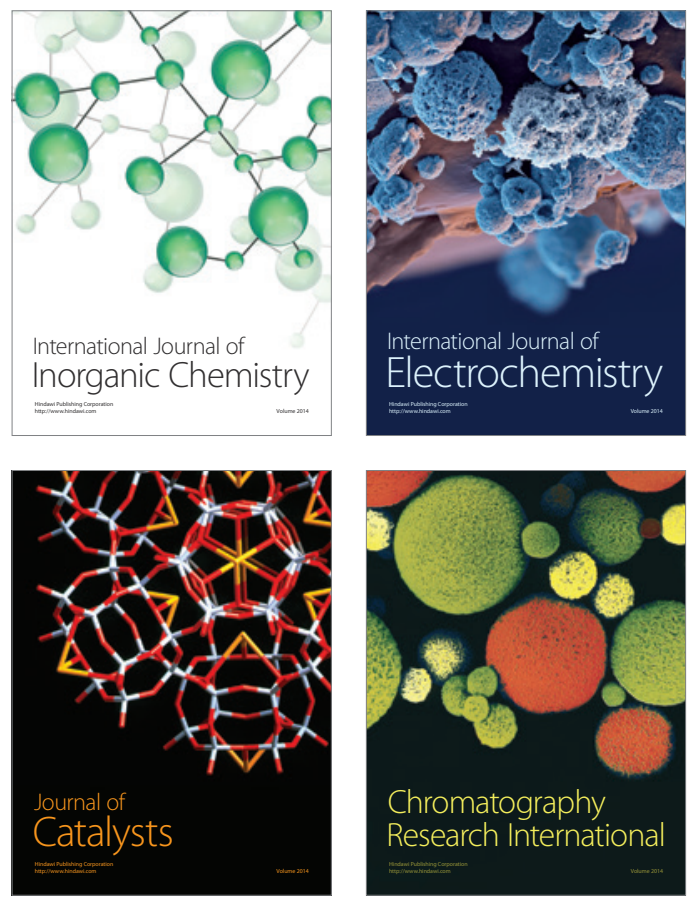
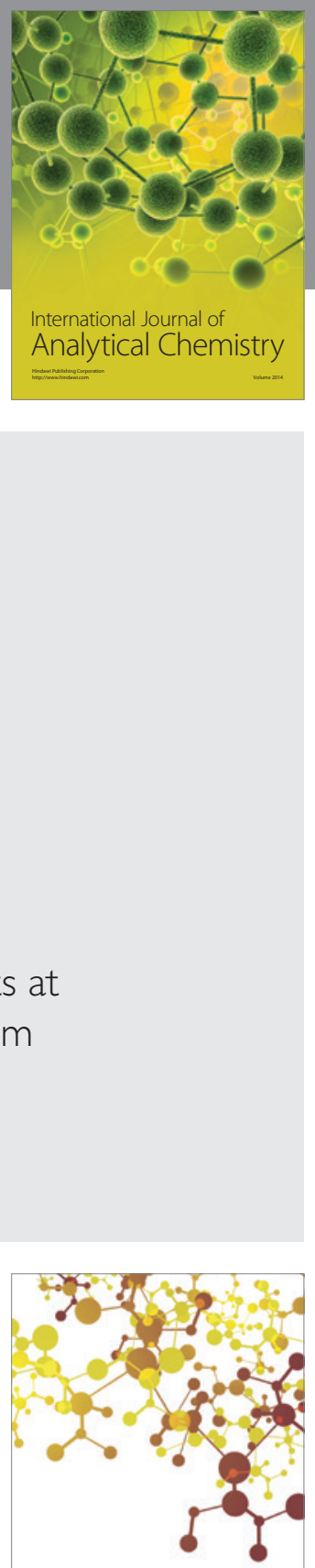

Journal of

Applied Chemistry
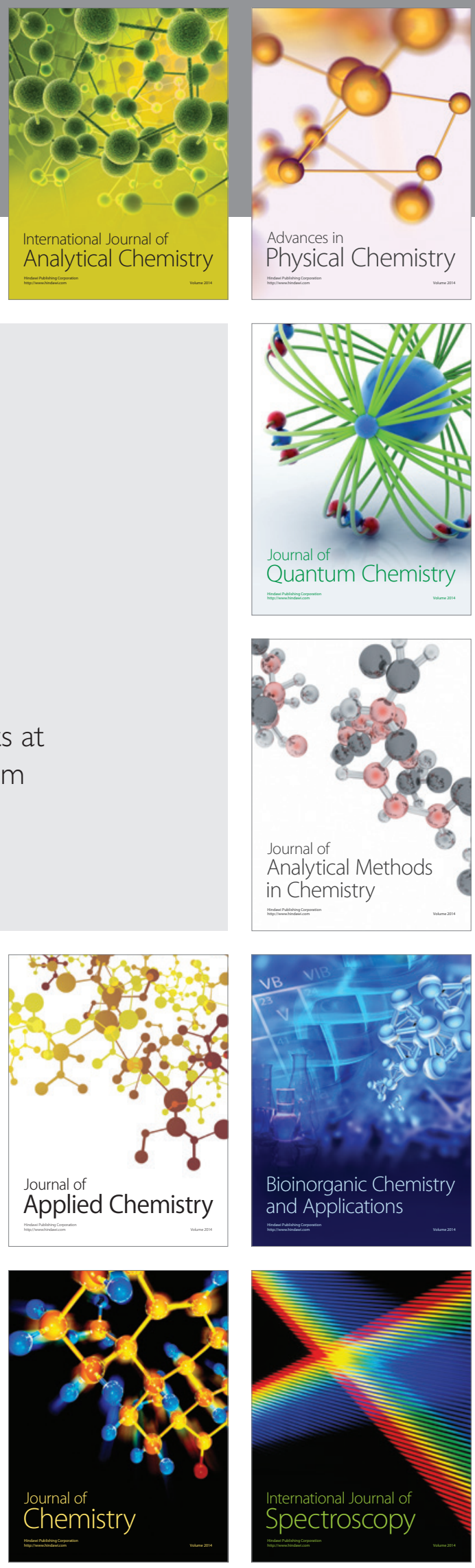